\title{
Impact of COVID-19 Pandemic on Indian Migrant Workers
}

\author{
Riyaz Ahamed Shaik ${ }^{1}$, Mohammed Nazeer ${ }^{2}$, Mohammad Muzammil Ahmed ${ }^{3}$ \\ ${ }^{1}$ Department of Community Medicine and Public Health, College of Medicine, Majmaah University, AlMajmaah, Saudi \\ Arabia. ${ }^{2,3}$ Department of Basic Medical Sciences, College of Medicine, Majmaah University, AlMajmaah, Saudi Arabia.
}

\section{ABSTRACT}

The coronaviruses are responsible for a variety of conditions like severe acute respiratory syndrome, common cold, and Middle East Respiratory Syndrome. Recently a new corona virus that was named later as Severe Acute Respiratory Syndrome Coronavirus 2 (SARS-CoV-2) was responsible for an outbreak that happened in Wuhan, China. The disease that the virus causes has been named as Coronavirus Disease 2019 (COVID-19) which has been declared by the world health organization as a global pandemic later in March 2020. The COVID-19 crisis is having an unprecedented impact on global economies, businesses and workers. Migrant workers are mostly from rural areas but live most of the year in cities for work. Many have no savings and lived-in factory dormitories, which were shut due to the lockdown. Indian migrant workers during the COVID-19 pandemic have faced multiple hardships. With factories and workplaces shut down due to the lockdown imposed in the country, millions of migrant workers had to deal with the loss of income, food shortages, and uncertainty about their future. Following this, many of them and their families went hungry. Thousands of them began walking back home, with no means of transport due to the lockdown. In response, the Central and State Governments took various measures to help them, and later arranged transport for them. With public health catastrophe unfolding because of the disease as well as economy, the need of the hour is to include all migrant workers in government initiatives and provide equitable access to treatment, detection and treatment measures besides economic and vocational assistance.

\section{KEY WORDS}

COVID-19, Migrant Labours, Response Measures and Lockdown
Corresponding Author: Dr. Riyaz Ahamed Shaik, Assistant Professor,

Department of Community Medicine and Public Health,

College of Medicine, Majmaah University, Al Majmaah - 11952, Saudi Arabia. E-mail: drriyazahamed@gmail.com

DOI: $10.14260 /$ jemds/2021/81

How to Cite This Article:

Shaik RA, Nazeer M, Ahamed MM, et al. Impact of COVID-19 pandemic on Indian migrant workers. J Evolution Med Dent Sci 2021;10(06):362-368, $10.14260 /$ jemds $/ 2021 / 81$

Submission 28-08-2020,

Peer Review 08-12-2020,

Acceptance 15-12-2020,

Published 08-02-2021.

Copyright (C) 2021 Riyaz Ahamed Shaik et al. This is an open access article distributed under Creative Commons Attribution License [Attribution 4.0 International (CC $B Y 4.0)]$ 


\section{BACKGROUND}

The coronavirus belongs to a family of viruses that may cause various symptoms such as pneumonia, fever, breathing difficulty, and lung infection. ${ }^{1}$ These viruses are common in animals worldwide, but very few cases have been known to affect humans. The World Health Organization (WHO) used the term 2019 novel coronavirus to refer to a coronavirus that affected the lower respiratory tract of patients with pneumonia in Wuhan, China on 29 December 2019. ${ }^{2}$ To date, there are no specific antiviral treatments or vaccines for SARS-CoV-2, and the clinical treatment of COVID-19 has been limited to support and palliative care until now. Therefore, there is an urgent need to develop a safe and stable COVID-19 vaccine. As on $26^{\text {th }}$ May, 2020 the coronavirus (COVID-19) is affecting 213 countries and territories around the world, where 5618126 people have been diagnosed positive, resulted 348,545 deaths, while 2,393,539 cases are recovered so far (Figure 1).

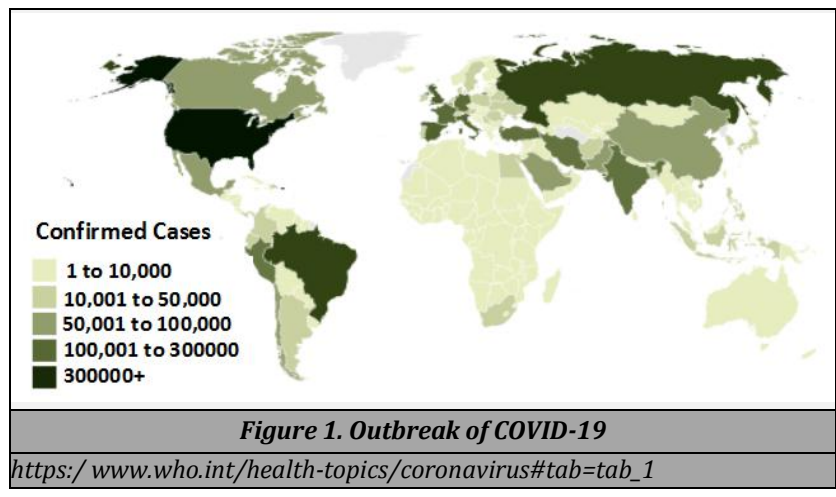

The episode of COVID-19 is growing with alarming rate in India where total corona positive cases as on May $26^{\text {th }}, 2020$, were 1,45,380, where 4,167 died and 60,491 recovered and sent home. As the coronavirus pandemic ripples around the world, it's affecting all of us. But it's having the most devastating impact on people invisible to many who are reading this: low-wage laborers who support large swathes of the global consumer economy. The International Labour Organization (ILO), a United Nations agency, estimates that this health crisis could increase global unemployment by nearly 80 million people, far exceeding the effects of the 2008 financial crisis. Western countries and corporations that have benefitted from inexpensive labour in low and middle-income countries now bear responsibility for easing workers' hardship ${ }^{1-3}$

Migrant is any person who is moving or has moved across an international border or within a State away from his / her habitual place of residence, regardless of his legal status, whether the movement is voluntary or involuntary; whatever the causes for the movement are; what the length of the stay is (IOM, 2011). In India, migrant labour is woven into the warp and weft of the economic fabric. It is a measure of the national economic integration as also of regional and ruralurban disparities that force migrants from weaker states to go to metros and other states in search of livelihood ${ }^{4-6}$. They contribute to the prosperity of their home and destination states, while empowering themselves ${ }^{7}$.

Large shares of migrants work under informal or casual arrangements, which leave them unprotected, vulnerable to exploitation, poverty and food insecurity, and often without access to healthcare, social protection and the measures being put in place by governments. Migrant workers are being hit hard. Business closures and restrictions to movement, combined with lack or limited access to all forms of social protection, increase migrants' vulnerability to poverty and food and nutrition insecurity. Loss of jobs and unstable incomes will hinder their capacity to access and purchase adequate and nutritious food for themselves and their families. Measurements of physical distancing are impacting services being delivered to migrants, including food delivery to the most vulnerable (e.g., migrants in transit, rejected asylum-seekers, homeless). While migrant workers in many countries are struggling to return to their rural areas of origin, return migrants are increasingly facing discrimination, being stigmatized as COVID-19 carriers. ${ }^{8}$ Adding on to school closures and disruptions in school feeding programmes, children in migrant families will be exposed to heightened risks of malnutrition and to child labour exploitation.

Document reports rising levels of discrimination and xenophobia against migrants and in some cases food insecurity, layoffs, worsening working conditions including reduction or non-payment of wages, cramped or inadequate living conditions, and increased restrictions on movements or forced returns (where they may be stigmatized as carriers of the virus). The impacts of the crisis might affect migrants differently, depending on their migratory or working status. If response measures are not adequately designed, many migrants risk of remaining unprotected and vulnerable to exploitation, poverty and food insecurity. Different types of migrants (e.g. refugees; internally displaced persons; migrant workers; internal or international; permanent, temporary or seasonal; documented or undocumented migrants) might have different access to work permits, social protection programmes, recovery measures and healthcare systems.

Response measures should focus on protecting workers at the workplace, expanding temporary work permits and ensuring safe mobility within and across countries, matching labour demand and supply, while protecting lives and livelihoods and supporting employment and incomes for the most vulnerable. All migrants should have access to response measures, including health and social protection, regardless of their migratory or working status ${ }^{9}$.

\section{IMPACT OF COVID-19 ON INDIAN ECONOMY} AND EMPLOYMENT STATUS

Recently an industry survey that is jointly conducted by industry body Ficci and tax consultancy Dhruva advisors and took responses from about 380 companies across the sectors. It is said that businesses are grappling with "tremendous uncertainty" about their future. According to the survey, COVID-19 is having a 'deep impact' on Indian businesses, over the coming month's jobs are at high risk because firms are looking for some reduction in manpower. Further, it is added that already COVID-19 crisis has caused an unprecedented collapse in economic activities over the last few weeks.6,8 The present situation is having a "high to very high" level impact on their business according to almost 72 per cent respondents. Further, 70 per cent of the surveyed 
firms are expecting a degrowth sales in the fiscal year 2020 21.

According to $\mathrm{Du}$ \& Bradstreet, COVID-19 no doubt disrupted human lives and global supply chain but the pandemic is a severe demand shock which has offset the green shoots of recovery of the Indian economy that was visible towards the end of 2019 and early 2020. The revised Gross Domestic Product (GDP) estimates for India downwards by 0.2 percentage points for the fiscal year 2020 to 4.8 per cent and by 0.5 per cent for the fiscal year 2021 to 6 per cent. Further, it is stated that the extent of the actual impact will depend upon the severity and duration of the outbreak. Further, according to the World Bank's assessment, India is expected to grow 1.5 per cent to 2.8 per cent. And IMF projected a GDP growth of 1.9 per cent for India in 2020 because the global economy is affected by the COVID pandemic, the worst recession since the Great Depression in the 1930s. ${ }^{9,10}$

According to the recent reports, labour market crunch right now can easily turn into a nightmare. Besides the possibility of social unrest, expect more demands for more reservations in government. The script is similar in many services industries, in manufacturing and non-manufacturing sectors such as construction. Lower growth because of falling demand and supply constraints would not only make fresh job creation tougher, but also hurt those who are currently employed. Overall, about 136 million non-agricultural jobs are at immediate risk, estimates based on National Sample Survey (NSS) and Periodic Labour Force Surveys (PLFS) data suggested. These are people who don't have a written contract and include casual labourers, those who work in non-registered nano businesses, registered small companies, and even the self-employed.6,8

\section{STATISTICS AND DATA ON MOVEMENTS}

The total number of internal migrants in India, as per the 2011 census, is 45.36 crore or $37 \%$ of the country's population. This includes inter-state migrants as well as migrants within each state, while the recent exodus is largely due to the movement of inter-state migrants. According to an estimate which is based on the 2011 Census, NSSO surveys and economic survey, show that there are a total of about 65 million inter-state migrants, and 33 per cent of these migrants are workers ${ }^{10}$.

By conservative estimates, 30 per cent of them are casual workers and another 30 per cent work on regular basis but in the informal sector. Uttar Pradesh and Bihar account for the origin of 25 per cent and 14 per cent of the total inter-state migrants, followed by Rajasthan and Madhya Pradesh, at 6 per cent and 5 per cent. This means that around $4-6$ million people would be wanting to return to Uttar Pradesh, and 1.8 2.8 million to Bihar. Another 700,000 to 1 million would be wanting to return to Rajasthan and 600,000 - 900,000 to Madhya Pradesh. Maharashtra has the largest number of migrants, according to the 2011 Census of India ${ }^{11}$.

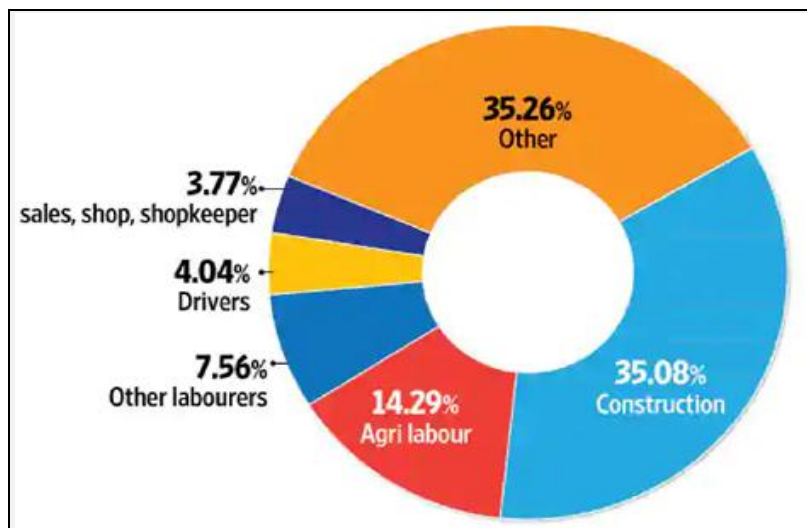

Figure 2. Source: Desai, Sonalde, Reeve Vanneman and NICAER, New Delhi India. Human Development Survey-II (IHDS - II), 2011-12

The nationwide lockdown in India which started about two month ago has impacted nearly 40 million internal migrants, where roughly 50,000 60,000 moved from urban centers to rural areas of origin in the span of a few days. Also, it is important to note that the magnitude of internal migration is about two-and-a-half times that of international migration. The State Government imposed a lockdown on 20 March in Pune, Pimpri-Chinchwad, the Mumbai Metropolitan Region, and Nagpur, leaving the migrant workers with no work. Thousands then gathered at the train termini and bus stations, seeking transport to their hometowns. With the nationwide lockdown, all transport facilities were closed.

\begin{tabular}{|c|c|c|c|}
\hline \multirow{2}{*}{\begin{tabular}{|c|} 
Rural Urban Status of \\
Place of Last Residence
\end{tabular}} & \multicolumn{3}{|c|}{ Rural Urban Status of Place of Enumeration } \\
\hline & Total & Rural & Urban \\
\hline Total & $97,560,320$ & $61,428,374$ & $36,131,946$ \\
\hline Rural & $73,949,607$ & $53,354,376$ & $20,595,231$ \\
\hline Urban & $20,655,277$ & $6,266,503$ & $14,388,774$ \\
\hline Unclassified & $2,955,436$ & $1,807,495$ & $1,147,941$ \\
\hline \multicolumn{4}{|c|}{ Table 1. Census of the India 2001} \\
\hline
\end{tabular}

Due to the lockdown, more than 300 deaths were reported, with reasons ranging from starvation, suicides, exhaustion, road and rail accidents, police brutality, and denial of timely medical care. Among the reported deaths, most were among the marginalised migrants and labourers. ${ }^{12}$

\section{PROBLEMS FACED BY WOMEN AND MEN MIGRANT WORKERS}

The economic disruptions caused by COVID-19 are having a huge impact on the Indian economy as tourist figures and merchandise exports have been severely affected by the pandemic, the slowdown of trading partner economies, and supply chain disruptions in many countries. According to the Reserve Bank of India data release, India's GDP could contract by 5.3 per cent in $2020^{13}$, a sharp lowering from its 2.8 per cent previous projections in December. Following global patterns, the decline of the economy will likely take a heavy toll on employment. The Indian Chamber of Commerce estimates that about 14.2 million jobs have already been lost, and the figure is likely to reach 20 million if the pandemic measure continue for 2 - 3 month $^{14}$.

Governments of various states in India have urged migrant workers to avoid travelling back to their states of origin at this time. Despite this, many migrant workers have 
returned home as for many, remaining in other states means no job, no income, no access to health care and risk of food shortages and homelessness ${ }^{15}$.

While there are no official figures available yet, ILO implementing partners indicate that migrant workers are among the first to lose their jobs as employers are downsizing their work forces. There are reports that in some cases, employers are confiscating migrant workers' personal documents, while others are continuing to work without being paid. While migrant workers who are losing their jobs are allowed to stay in different states seek new employment, few are reportedly able to find new jobs ${ }^{16}$.

Among those that are still employed, there are some reports that migrant workers are excluded from the distribution of PPE (masks and hand sanitizer) at the workplace level. While there are exceptions, information about COVID-19 and how to protect against contamination is mostly made available in India, excluding many migrant workers from this critical information. Further, distancing measures are difficult to implement where migrant workers are living in cramped dormitories and other housing facilities with overall poor sanitary conditions. ${ }^{17-18}$

Migrant workers in certain occupations face heightened risk. The partial lockdown exempts construction, a sector heavily dependent on migrant workers. Many migrants are heading to work on high-rise buildings and apartment complexes and building sites, with only a few wearing face masks or bandanas around their nose and mouth. Some domestic workers have been dismissed by employers of fear for bringing COVID-19 into the home where they work, while those that have continued to work have reported of not being given a day off and having to work long hours for no extra pay ${ }^{19}$. Workers in entertainment and retail are also losing jobs due to the requirement to shut down such businesses during this period. ${ }^{20}$

While migrant workers have the same right to access social security including health care and paid sick leave as other regular workers, in reality many are excluded. This includes migrants working in the informal sectors (including domestic work, agriculture, and fishing), regular workers whose employers for various reasons have not enrolled them in the social security system, and undocumented migrant workers. These groups have limited access to COVID-19 testing and treatment and might not seek medical support due to costs involved, and fear of the repercussions of engaging with authorities, including deportation for those in irregular status. Pregnant women migrants within these groups may not be able to access necessary medical care, and women if they face violence, may not be able to access essential health and social services further, de facto, there are barriers for formal sector workers in accessing unemployment insurance. ${ }^{21}$

Previous epidemics globally have seen increased rates of violence against women as freedom is restricted, economic tensions are felt, and women are isolated from support systems. While official data is not available, critical services for women workers and especially women migrant workers facing violence is important. Ahead of the Emergency Decree coming into effect on 20 March, all land borders were closed, but many have since reopened, and some closed again in response to the number of migrants attempting to cross. The uncertainty surrounding border closures has added to the sense of panic felt within migrant communities during this public health emergency and has led to more migrants crossing at non-official crossing points.

The movement of migrant workers returning to their places of origin and across the borders to Myanmar, Lao People's Democratic Republic and Cambodia has created significant pressure on front line immigration officials and increases the risks of new clusters of people infected with COVID-19. Meanwhile, detention of migrants in an irregular situation continues, raising concerns about their health within the Immigration Detention Centres.

Migrants who have left their workplaces and returned to their states of origin also face challenges. The states of origin are quarantining migrant returnees. Initially this was done as self-regulated home quarantine but more recently at government or community-based quarantine centres close to their homes. ${ }^{22}$ These centres have limited capacity, and there is not enough information available for migrant workers about these centres and how they are operated. In some cases, returnees are met by fear from their community members which may fuel stigmatization and discrimination.

\section{Food Shortage}

According to government reports, there was enough food grain stocked up in the FCI godowns to feed the poor for at least a year-and-a-half. While government schemes ensured that the poor would get additional rations due to the lockdown, the distribution system failed to be effective as the ration cards are area-specific and fair price shops were largely inaccessible. Additionally, the 'One Nation, One Ration Card' system ${ }^{23}$ has been implemented in very few states, as of mid-April. While the scheme allowed migrant workers to retrieve food grains for free anywhere across the country, very few are aware of the scheme. In addition to this, the scheme also requires biometric authentication, which was discontinued due to fears of spreading the virus through common fingerprint sensors. In Telangana, many could not avail of the ration due to a lack of Aadhaar cards. ${ }^{24-25}$

\section{RESPONSES BY GOVERNMENTS TO ASSIST MIGRANT WORKERS}

\section{Relief Camps}

Soon after the central government directive in late March, state governments set up thousands of camps to house lakhs of migrants and stop the exodus. Delhi government provided free food to 4 lakh people every day, as of late March. Over 500 hunger relief centres were set up by the Delhi government. As of 12 April, 37,978 relief camps and 26,225 food camps had been set up. ${ }^{26-27}$

By 5 April 75 lakh people were being provided food across the country in food caps run by the government and NGOs. To cater to the needs of the migrants and prevent them from leaving the camps, the governments of Kerala changed the food being provided by adding north Indian dishes to the menu, providing carom boards and recharge facilities for phones, as well as provide other medical essentials such as masks, sanitizers, and medicines ${ }^{28-30}$. 


\section{Transport Arrangements}

In late March, the Uttar Pradesh government decided to arrange buses at Delhi's Anand Vihar bus station to take the migrants back to their villages for free. Large crowds then gathered at the bus station. However, with the extension of the lockdown, many remained stranded till the last week of April, when the state governments were permitted by the central government to operate buses, but not trains. ${ }^{31}$

On 1 May, the central government permitted the Indian Railways to launch "Shramik Special" trains for the migrant workers and others stranded. On 3 May, the Ministry of Home Affairs mildly reprimanded the state governments for hurriedly requesting for trains to transport migrants, stating that the trains were primarily mainly meant for those who were stranded due to the sudden lockdown, and not the migrants. Additionally, this service was not free, with additional charges over the normal fares. ${ }^{32-33}$ The central government then faced criticism from the opposition, with the Indian National Congress promising to sponsor the tickets of the migrants on 4 May. The government then announced that the Railways would offer an $85 \%$ subsidy on the train fares, with the state governments funding the remaining 15 $\%$. However, the migrants were still forced to pay an undisclosed amount. ${ }^{34-36}$ The central government further declined to share the details regarding this with the Supreme Court. ${ }^{37}$

The central governments directives regarding which states should pay for the migrants' travel resulted in disagreement between Maharashtra and other states. According to the Stranded Workers Action Network (SWAN), migrants were confused about the exact procedures to register themselves for travel. Additionally, many state registration portals were either in English or the local language of the states they lived in, which very few migrants could understand. Further, general lack of information from the government to the migrants had resulted in them paying large sums of money to register themselves. ${ }^{38-40}$

A few days after the Shramik Special trains were introduced, the Karnataka government cancelled the trains (reportedly supporting the construction industry) and the Bihar government did the same to trains coming from Kerala (refusing to provide a No-Objection Certificate). The two states later reverted their decisions. ${ }^{41}$

As of 22 May, 2,317 Shramik Special trains had transported more than 31 lakh migrant workers. $50 \%$ of the coaches converted into COVID-19 care centres were used for these trains. As per a report given by the Indian Railways on 23 May, migrant labourers from Bihar and Uttar Pradesh comprised $80 \%$ of the train journeys. Additionally, it was expected that 36 lakh migrants would be travelling in the ten days after the report. 42

\section{Relief Measures}

Soon after the nationwide lockdown was announced in late March, Finance Minister (FM) announced a Rs. 1.7 lakh crore (US \$ 24 billion) spending plan for the poor. This consisted of cash transfers and steps to ensure food security. Rs. 1,000 crores from the PM CARES Fund was allocated for the support of migrant workers on 13 May. On 14 May, FM further announced free food grains for the migrant workers, targeting 80 million migrant workers by spending 035 billion (US $\$ 490$ million). ${ }^{35}$

\section{Policy Recommendations}

To avoid returning of migrant workers employed in all sectors and sub-sectors attentions must be drawn. This will mitigate labour shortages caused by travel restrictions on incoming labour by ensuring that those workers who want to stay do not need to leave their workplaces, while also reducing the possibility of spreading the virus to other areas upon their return. ${ }^{43}$

Ensure the safe movement of organized and unorganized sector workers within countries, including during lockdown, and between countries, allowing exceptions in granting working visas to seasonal workers ${ }^{44}$. This will minimize shortfalls and maintain essential services, while retaining workers' safety, health surveillance and containment as the primary criteria. 45

Regularize migrants present in the territory and grant temporary work permits to all. Regularization and issuance of temporary work permits will ensure that undocumented migrants or those migrants who, under certain circumstances, cannot work (e.g. asylum seekers) can have access to jobs, thereby filling the shortfall of workers coming from different states and abroad. This will also ensure that migrants have access to healthcare, support services and social protection measures to mitigate the socio-economic impact of COVID-19.46

Match the demand for labour of all the sectors with the migrant labour supply. Promote online appeals or other forms of labour matching, giving the opportunity to all migrants present in the country, especially those who lost their jobs due to business closures, to access jobs in the agrifood systems. Promote social dialogue and consultations with producers' organizations to put in place dedicated measures to support smallholder / family farmers and small-medium agricultural enterprises that may face several constraints (e.g. no or limited access to information, ICTs, lack of labour) in matching labour needs. ${ }^{47}$

Ensure occupational safety and health measures are put in place and are accessible to all migrants. Personal protective equipment and related items should be distributed to all workers employed in indispensable services, including those working in the food and agricultural sector. Ensure adequate hygiene and sanitation is provided and physical distancing is respected at the workplace, in housing for migrant workers (when provided by employers or the state), and on the means of transportation required to reach the fields / workplaces in remote rural areas. ${ }^{48-50}$

Information and awareness raising campaigns on how to protect oneself and others from the risk of infection need to be made accessible in languages and communication channels / formats that are understandable and accessible to all migrant workers. ${ }^{51}$

Ensure the inclusion of all migrants in the pandemic response and in the measures that are being introduced to mitigate the economic recession caused by COVID-19, regardless of the migratory or working status. Migrants should be given equitable access to prevention, detection and treatment measures. Social protection, income smoothing and employment retention measures should be expanded to 
cover all vulnerable populations, including all migrants. 52 Particular attention needs to be placed on the most vulnerable subgroups, including women, youth and children (including parental care support for migrants working in indispensable services), older migrant workers with comorbidities (such as HIV-AIDS, tuberculosis, diabetes, disability), and on unprotected workers, including the selfemployed, contributing family workers, casual, seasonal, and informal workers, and gig workers in the food and agricultural sub-sectors. Time-bound financial and tax relief need to extend to micro, small and medium-sized enterprises in all agricultural sub-sectors owned by migrants. ${ }^{52-56}$

\section{CONCLUSIONS}

A highly infectious and novel virus, Covid-19 has pushed the state and central governments into the uncharted policy and action territory, without the availability of any vaccine or treatment. Unlike China, which militarily enforced the lockdown of a similar scale and scope, doing so in a democracy like India - a socially and federally diverse, but economically weak country-poses a unique challenge. The migrant crisis is emblematic of this, and needs special initiatives. Governments need to address the challenges being faced by internal migrants by including them in health services and through cash transfer and other social programmes, and by protecting them from discrimination. As the early phases of the crisis unfolded, many international migrants, especially from the Gulf countries, returned to India until travel restrictions halted these flows. Some migrants had to be evacuated by governments, such as from China and Iran. It is equally important to collect and update comprehensive migrant worker-related data and statistics, going beyond the 10-year census exercise categorising them into skill, sector and gender at the state and national level. Its absence has blindsided us on the scale of the migrant labour challenge and frustrated efforts to reach them to help with food, cash transfers, health services, shelter or in relocating them to home / host states.

Financial or other competing interests: None.

Disclosure forms provided by the authors are available with the full text of this article at jemds.com.

\section{REFERENCES}

[1] Joanna S, Niha M. In India, the world's biggest lockdown has forced migrants to walk hundreds of miles home. The Washington Post. 13 May 2020, 28 March 2020.

[2] Singh K. Coronavirus outbreak: ensuring water, hygiene facilities for migrant labourers can safeguard millions stranded during shutdown. Firstpost 6 April, 2020.

[3] Abi-Habib M, Yasir S. India's Coronavirus lockdown leaves vast numbers stranded and hungry. The New York Times 29 March, 2020.

[4] Rashid O, Anand J, Mahale A. India coronavirus lockdown - Migrant workers and their long march to uncertainty. The Hindu 4 April, 2020.
[5] More than 21,000 camps set up for over $6,60,000$ migrants: State governments. The Economic Times 1 April, 2020.

[6] Coronavirus lockdown - Over 60,000 people have registered on Delhi govt portal to go back home. The Hindu Press Trust of India 15 May, 2020.

[7] India to provide free food grains to millions of migrant workers. The New York Times Reuters 14 May, 2020.

[8] Gunasekar A, Sanyal A. Buses not feasible for moving migrants, states appeal to centre: sources. NDTV 30 April, 2020.

[9] Bhargava Y. Coronavirus lockdown - railways to run 'Shramik Special' trains to move migrant workers, other stranded persons. The Hindu 1 May, 2020.

[10] Nair S, Verma D. A policy framework For India's COVID19 migration. Bloomberg Quint 19 May, 2020.

[11] Frayer L, Pathak S. Coronavirus lockdown sends migrant workers on a long and risky trip home. NPR 31 March, 2020.

[12] Srivastava R, Nagaraj A. As migrant workers struggle for lockdown aid, India seeks to count them. Reuters 29 April, 2020.

[13] Sharma M. Coronavirus exposes India's official callousness. Bloomberg Quint 1 April, 2020.

[14] Dutt B. There is a humanitarian crisis in India. Lift the lockdown, now. Hindustan Times15 May, 2020.

[15] Babu V, Saini S, Swaroop V. Across the country, migrants still forced to walk thousands of miles. Hindustan Times 8 May, 2020.

[16] Elsa E. Coronavirus lockdown: 12-year-old Indian migrant worker walks $100 \mathrm{~km}$, dies just $11 \mathrm{~km}$ away from home. Gulf News 21 April, 2020.

[17] Warsi Z. 42 Migrant workers died in road accidents while trying to return home during lockdown: report. News18 7 May, 2020.

[18] Shantha S. Gujarat police to probe allegation that migrant workers were forced into container trucks. The Wire 7 April, 2020.

[19] Nandi S, Bhaskar U. Migrants' deaths on the tracks a wake-up call for India. Livemint 8 May, 2020.

[20] Auraiya road accident: two more migrant workers die, toll rises to 26. Hindustan Times 19 May, 2020.

[21] Venkatraman T, Chauhan S, Dey S, et al. In long walk back home, migrants battle hunger, scourge of COVID-19. Hindustan Times 16 May, 2020.

[22] AP PHOTOS: An army of Indian migrant workers heads home. The New York Times. The Associated Press 16 May, 2020.

[23] Gunjan RK. Impatient, starving, angry: as India extends lockdown, stranded migrant workers emerge as crisis in making. News18. 15 April, 2020.

[24] Jebaraj P. Inter-state ration card portability usage very low: food minister. The Hindu 8 May, 2020.

[25] Vadlamudi S. Sans Aadhaar, no ration for migrants. The Hindu 19 April 2020.

[26] Coronavirus - Delhi govt to feed 4 lakh people from tomorrow; ready for even 1,000 cases a day, says Kejriwal. The Hindu 27 March, 2020.

[27] Mathur A. Delhi lockdown: over 500 hunger relief centres set up for 4 lakh people. The Times of India 28 March, 2020. 
[28] COVID-19 situation: Nearly 38,000 relief camps set up for migrant labourers, Govt to SC. The Indian Express 27 April, 2020.

[29] Over 75 lakh being fed at food camps: MHA. The Tribune 6 April, 2020.

[30] Arnimesh S. Rotis, mobile recharges, carrom boards how Kerala fixed its migrant worker anger. ThePrint 18 April, 2020.

[31] Jha S. Fighting COVID-19: after the long walk, jobless migrants head home by bus. Business Standard India 29 March, 2020.

[32] Gupta S. Send only stranded migrants: centre tells states. Hindustan Times 3 May, 2020.

[33] Shramik special trains - Migrant workers, other stranded people to pay $\square 50$ more to get home. The Hindu 2 May, 2020.

[34] Varma AG. Congress' move to sponsor rail fare for migrants sparks political tussle. Livemint 4 May, 2020.

[35] Humble contribution: Sonia Gandhi says congress to bear rail travel cost of migrant workers, Slams Govt. news18.com. 4 May, 2020.

[36] Under Opposition Pressure, Modi Govt issues misleading explanation on migrants' rail fare breakdown. The Wire 5 May, 2020.

[37] Government can't tell Supreme Court if it is paying 85\% rail fare. The Telegraph. Kolkota 6 May, 2020.

[38] Saha P. Migrants' fare row: States paying for special trains, only Maharashtra charging. India Today 4 May, 2020.

[39] Mitra R. Migrant workers do not know procedures: stranded workers action network. The New Indian Express 13 May, 2020.

[40] Kulkarni C. Coronavirus lockdown: Karnataka cancels inter-state trains fearing labour shortage. Deccan Herald 6 May, 2020.

[41] Coronavirus - 5 trains cancelled in Kerala over NOC. The Hindu 5 May 2020.

[42] Sharma M. 4 Migrant trains from Karnataka today as services restart after criticism. NDTV 9 May, 2020.
[43] Vaidyanathan A. Supreme court to hear petition on migrants amid lockdown today. NDTV 29 March, 2020.

[44] Panic, fear bigger problem than coronavirus': sc on plea on migrant workers' exodus. Outlook 30 March, 2020.

[45] Plea on state of migrant workers: SC says it doesn't want to interfere in govt decisions. The Indian Express 8 April, 2020.

[46] Chaturvedi A. Government effort to restrain media coverage of pandemic met with supreme court caution. Bloomberg Quint 1 April, 2020.

[47] Rajalakshmi TK. Centre blames media 'fake news' for mass migration during lockdown. The Hindu Frontline 1 April, 2020.

[48] Judiciary failed to protect citizens' rights amid COVID-19 pandemic: dushyant dave. Hindustan Times 23 May, 2020.

[49] Ananthakrishnan G. Can't stop or monitor their movement on roads': SC rejects plea seeking relief for migrants. The Indian Express 16 May, 2020.

[50] Coronavirus lockdown: Image of a weeping Rampukar Pandit becomes symbol of India's migrant worker tragedy. The Hindu. Press Trust of India 17 May, 2020.

[51] Elsa E. The human cost of India's coronavirus lockdown: deaths by hunger, starvation, suicide and more. Gulf News 15 April, 2020.

[52] Suicide leading cause for over 300 lockdown deaths in India, says study. The Economic Times 5 May, 2020.

[53] Gettleman J, Raj S, Kumar H. As India reopens, deadly accidents break out. The New York Times 8 May, 2020.

[54] Mohanty D. 56-year-old migrant dies on road to home, another dies after police lathi charge. Hindustan Times 15 May, 2020.

[55] Vij S. More than 300 Indians have died of the coronavirus, and nearly 200 of the lockdown. ThePrint 13 April 2020.

[56] Agarwal K. Not Just the Aurangabad accident, 383 people have died due to the punitive lockdown. The Wire 10 May, 2020. 